\title{
PENTA HELIX COMMUNICATION MODEL THROUGH COMMUNITY BASED TOURISM (CBT) FOR TOURISM VILLAGE DEVELOPMENT IN KOTO SENTAJO, RIAU, INDONESIA
}

\author{
Yasir YASIR* \\ Universitas Riau, Faculty of Social and Political Sciences, \\ Department of Communication Science, Indonesia, e-mail: yasir@lecturer.unri.ac.id \\ Yohannes FIRZAL \\ Universitas Riau, Faculty of Engineering, Department of Architecture, Indonesia, e-mail: yfirzal@eng.unri.ac.id \\ Andri SULISTYANI \\ Universitas Riau, Faculty of Social and Political Sciences, \\ Department of Travel Agency, Indonesia, e-mail: andri.sulistyani@lecturer.unri.ac.id
}

\section{Chelsy YESICHA}

Universitas Riau, Faculty of Social and Political Sciences, Department of Communication Studies, Indonesia, e-mail: chelsy.yesicha@lecturer.unri.ac.id

\begin{abstract}
Citation: Yasir, Y., Firzal, Y., Sulistyani, A., \& Yesicha, C. (2021). PENTA HELIX COMMUNICATION MODEL THROUGH COMMUNITY BASED TOURISM (CBT) FOR TOURISM VILLAGE DEVELOPMENT IN KOTO SENTAJO, RIAU, INDONESIA. GeoJournal of Tourism and Geosites, 37(3), 851-860. https://doi.org/10.30892/gtg.37316-718
\end{abstract}

\begin{abstract}
This study aims to explain the higher education institution's role in developing Koto Sentajo as tourism village and to understand the tourism communication model that synergizes with other stakeholders. This study uses a qualitative approach that emphasizes more on depth. The method describing is done by the reality that occurs by interacting directly with the research subject. The results showed that higher education institutions have an essential role in developing a tourism village development model. This communication model is useful for attracting local governments and other stakeholders to establish the Koto Sentajo tourism village. The penta helix communication model involves five main actors, namely the campus, corporate CSR, the community, the mass media, and the Kuantan Singingi regency's local government, to develop the tourism village. The communication and collaboration between stakeholders in empowering the community can accelerate the Koto Sentajo tourism village's realization as a leading cultural heritage destination.
\end{abstract}

Key words: tourism communication, community-based tourism, penta helix, tourism village, cultural heritage

$* * * * * *$

\section{INTRODUCTION}

The tourism industry can affect economic and community development (Fan et al., 2018; Strydom et al., 2019). Tourism can also contribute to economic growth and increase community sources of income, both directly and indirectly (Ali, 2018; Nagarjuna, 2015). Even tourism has contributed to fighting economic inequality (Giampiccoli, 2020). Tourism development increases economic growth, reduces poverty, and conserves natural and cultural resources (Tripathi and Munjal, 2014). Therefore, tourism development certainly has a vital role in improving people's welfare. The community is the main stakeholder in the process of achieving sustainable development (Lundberg, 2017). Community suppots are significantly affecting sustainability of tourism industry (Carr et al., 2016). Therefore, community involvement is also the main element in reflecting indigenous people democratic rights in tourism development communication (Istiyanto, 2011). This communication also encourages them as actors to have awareness and mutual support of the importance of tourism development. Tourism development based on rural communities can drive small and medium scale industries that can be carried out in a labour-intensive manner and grow rural communities' economy. Micro, Small and Medium Enterprises (MSMEs) play a role in advancing the Indonesian economy because they can absorb labour and reduce unemployment (Bahri and Prasetyo, 2020). Based on this assumption, the government has proclaimed various steps to optimize village communities' empowerment level as the primary stakeholder. One form is the tourism village development program.

Tourism villages can be a driving force for creating economic growth based on the concept of local wisdoms. It can grow independently from within villagers groups and develop rapidly with government supports. The mandate of Law No.10 of 2009 states that tourism development is a national development carried out in a systematic, planned, integrated, sustainable and responsible manner while still protecting religious, cultural values that exist among society, environmental preservation, and national interests (Indonesian Government, 2009). This tourism development is aimed to encourage equal opportunity in running any business and also obtaining benefits derived from the changing of local, national and global live

\footnotetext{
* Corresponding author
} 
challenges. Koto Sentajo is a village located in Kuantan Singingi Regency, Riau Province, Indonesia, that can be developed as a centre for the local culture-based tourism industry. This village has not been well developed and managed by the Kuantan Singingi Regency government. This village has 27 traditional houses known as Rumah Godang. These traditional houses are the custom centre of Rang Sentajo (people of Sentajo ethnic groups) and as the place to gathering for the four major ethnic groups in Sentajo, which are including melayu, caniago, patopang and Peliang ethnic groups. This area is very unique because its traditionality has still well maintained by indigenous people.

Tourism management and promotion activities in Koto Sentajo Village have not been optimal due to the absence of a simultaneous mentoring program from the local government. Besides, budget constraints, conflicts of interest, and no placement of priority tourism objects have made tourism development less optimal (Chamidah et al., 2020). This paper assumes that the tourism communication approach based on community-based tourism (CBT) in assisting tourism villages positively impacts the local community and the surrounding community. Currently, the tourism market is rapidly growing based on cultural tourism, becoming a new trend for tourists (Martínez et al., 2014). The direction of interest and attention to tourism experiences has changed a lot towards traditional cultural tourism and the natural environment (Santos et al., 2016). However, tourists must have smart criteria and features to be visited by tourists such as leadership, innovation, social capital and ICT infrastructure (Boes et al., 2016). This interest and attention have also concerned by tourism experts regarding the importance of tourism development that is based on local communities and the environment. The activities can be carried out through ecotourism, indigenous cultural tourism, and sustainable tourism. Eco-based tourism has become a concern because of government policies' direct impact on the environment and ecology (Do et al., 2015).

Although previous tourism studies have contributed significantly to explaining how cultural tourism enhances local economic development, in practice, the development, protection and expansion of culture-based tourism also require understanding and empowering local communities. Collaboration among stakeholders has an essential role in community development through CBT to equalize the economy and tourism resources (Giampiccoli, 2020). The tourism development policy is an effort to encourage actors in the tourism sector to improve community welfare. Development based on culture or local wisdom and tourism has seen from two mutually supportive sides. In its development, the community has involved not only as an object but also as a subject of the action. Tourism development is carried out through a whole and integrated systemic approach. Building community awareness of environmental conservation and tourism development is crucial because it directly impacts its development (Garcias, 2012). As the main stakeholders of village development, village residents are essential as the main subject because, without their support, tourism development will not be sustainable (Lundberg, 2017). Based on this, the authors aims to explain the role of higher education institutions in developing Koto Sentajo as a tourism village and to understand the tourism communication model in developing a tourist village.

\section{Literature Review}

Many studies have shown that tourism development can create jobs and increase people's income. Tourism is a significant source of income and economic activity in developing countries (Nagarjuna, 2015). Tourism can create a market for local producers and protect people's cultural heritage (Fan et al., 2018; Sinclair-Maragh, 2017). In this case, the local community plays a vital role in tourism development because it can increase trust in the tourism industry. Local communities' involvement is essential because the community's decision-making will encourage a sense of belonging and have the same goals (Nagarjuna, 2015). Even the theory of tourism competitiveness explains that the population's welfare is the primary basis for a destination's success (Perles-Ribes et al., 2020).

In several studies, tourism has a significant relationship with environmental and humanitarian concerns (Pung and Chiappa, 2020). The current growth of environmental awareness directs tourism development to carry out sustainably. Natural and cultural tourism resources are the heritage that must be protected. Protection of natural and cultural resources is the most crucial thing in sustainable development (Muzapu and Sibanda, 2016). The development of a sustainable tourism village requires assistance that is oriented towards empowering the local community as a development subject (Ridlwan et al., 2017). Tourism village development based on community empowerment aims to increase community capacity to identify problems independently, potentials and needs of the community, conduct social, economic and environmental impact studies and manage and market their villages to attract tourists (Noor and Nala, 2020). Community-based tourism (CBT) research addresses empowerment, independence, social justice, welfare and sustainable development (Khamdevi and Bott, 2018; Mtapuri and Giampiccoli, 2020; Sumarmi et al., 2020). CBT has various principles and characteristics, mainly intended to fight, oppose and reduce inequality of control of tourism resources. Community participation and equality in planning, decision making, management, ownership and distribution of benefits belong to the community. CBT is different from tourism managed by neo-colonialists that tend to ignore local communities (Giampiccoli, 2020; Sumarmi et al., 2020). CBT is a means to ensure the tourism industry benefits residents that will improve the community's standard and quality of life. CBT can be considered a means of integrating sustainable development goals, namely minimizing environmental and cultural damage, optimizing visitor satisfaction and maximizing long-term economic growth (Strydom et al., 2019). In other words, sustainable tourism does not drain economic, social/cultural and environmental resources and can even strengthen and make people aware of the culture and the environment.

Several other studies have shown that cultural heritage-based tourism, both culinary and architectural, is very useful in being used as a local economic development strategy (Gumede, 2019; Tripathi and Munjal, 2014; Wang et al., 2009). Heritage tourism contributes significantly to understanding in providing opportunities for cultural, historical, and 
community interaction because elements of education and information about heritage sites also become significant motivations for visitors (Wang et al., 2009). Various stakeholders such as the private sector, government, civil society and local communities play an important role in tourism development. The integration of tourism development through the penta helix concept has widely developed in Indonesia's tourism development research (Chamidah et al., 2020). Penta helix is a socio-economic development model that encourages mutually beneficial cooperation through the synergy of the government, academia, society, the business world, and the mass media to realize tourism development (Halibas et al., 2017). The penta helix model focuses on activities that arouse feelings and involve individuals or groups in an activity. This model is essential because social innovation development will not be successful without affecting the community to solve society's problems (Lindberg et al., 2015). In this case, the development of tourist destinations requires all society components, especially local communities' awareness (Yasir et al., 2019).

Therefore, the attitude of citizens towards tourism is an essential concern in tourism development because they are the ones who are directly affected by its development (Sinclair-Maragh, 2017). Local community-based tourism can develop individual economies, residents, and places where tourism has developed (Carr et al., 2016). Community-based sustainable tourism development is not only beneficial for economic growth, but it can also restore social harmony and integration, and preserve cultural heritage, eliminate social conflict and restore peace (Mohanty et al., 2019). At present, mass tourism can indeed harm the natural, social, and cultural environment, even though tourism contributes to economic growth for small businesses and people's lives (Khamdevi and Bott, 2018).

Related studies show a shift that mass-based tourism and large capital owners have been displaced by communitybased tourism because it is more sustainable (Mtapuri and Giampiccoli, 2020). This CBT appears to fight against the existence of conventional tourism, which has generally controlled by big investors (Giampiccoli, 2020). This community-based tourism development model is an alternative to conventional or mass tourism. The existence of the CBT facilitates the redistribution of wealth, power and tourism resources. In essence, CBT is the best approach to sustainable tourism development in encouraging local communities to play an active role (Sumarmi et al., 2020).

Community-based research shows that several factors can influence people's perceptions and attitudes towards tourism (Chiappa et al., 2019). Tourism has both positive and negative impacts on local communities (Giampiccoli, 2020). Public attitudes and support for tourism can decrease if they negatively view tourism (Sinclair-Maragh, 2017). Various intrinsic and extrinsic factors can characterize the perspective of the community regarding tourism. Intrinsic factors refer to individual characteristics and aspects of the population, such as socio-demographic characteristics (for example, gender, education level, age, proximity to tourist areas, etc.). The intrinsic factor also refers to their economic dependence on tourism activities, beliefs and feelings generated by the tourism phenomenon. Meanwhile, extrinsic factors refer to a destination's characteristics, such as the tourism development stage, the tourist-guest ratio, the tourism season, and the types of tourists visiting the destination. According to the Tourism Area Life Cycle theory, these factors have considered because there is a relationship between population attitudes and the different phases of the tourism life cycle (i.e. exploration, engagement, development, consolidation, stagnation and decline).

At first, the residents may have a positive attitude towards visitors, but local people start to worry about the tourism phenomenon's impact as their numbers increase. As the number of tourists increases, the population will experience four main stages: euphoria, apathy, irritation and antagonism (Chiappa et al., 2019). In anticipating the problem, sustainable tourism development needs to consider communication that can sustainably foster local communities. Therefore, mentoring is required to identify which communities are active in tourism activities (Nagarjuna, 2015). Communication activities in marketing tourism destinations require effective communication through optimal management (Chamidah et al., 2020). Communication is a social process where individuals use symbols to create and interpret meaning in their environment (West and Turner, 2008). In this sense, social exchange theory argues that if residents believe that tourism development benefits outweigh the costs, they are more likely to support development programs. This community-based tourism has its challenges, constraints and limitations (Giampiccoli, 2020). Hence, it is important to utilize existing communication resources to overcome these obstacles and limitations. The development of an adequate tourism communication channel is significant. Social media such as Facebook, Instagram and YouTube have played an essential role in promoting the destination's image in audio and visual form (Nghiêm-Phú and Bagul, 2020). Visual and auditory images presented on social media concerning destinations can influence the formation of cognitive and affective images and tourists' intentions.

\section{MATERIALS AND METHODS}

This research used a qualitative research methods using an interactive model design. This model consists of several components that influence and are influenced by each other, namely: goals, conceptual framework, methods, research questions and validity (Maxwell, 2014). This study aims to explain in depth the phenomena related to communication and coordination of tourism village assistance through data collection and to describe as broadly as possible. This research emphasizes on data depth rather than the quantity of data. The descriptive method creates a systematic, factual, and accurate descriptions of facts. Research with qualitative methods describes the reality that occurs by interacting directly with the subject under study (Hrycyk et al., 2020). This research was done in Koto Sentajo Village, Koto Sentajo Raya District, Kuantan Singingi Regency, Riau Province, Indonesia. The study has conducted for more than one year between August 2019 and November 2020. The research informants were the head of the Koto Sentajo village, the head of the Koto Sentajo sub-district, the head of the Kuantan Singingi tourism office, the manager of the Koto Sentajo Tourism Awareness Group (Pokdarwis), traditional leaders (datuk) and villagers. The datas collected through discussion, interviews, observation, and documentation based on the focus of the problems studied related to communication forms carried out 
during the tourism village assistance process by stakeholders. The focus of this study was collected, processed, analyzed and presented in a descriptive form. This research has directly involved community empowerment because it has the power in depth and detail in discussing situations, programs, events, people, interactions, and behaviours observed (Moleong, 2010). Following qualitative research rules, the researchers act as the main instrument or tool during this research. Therefore, the research process is flexible following the development of the study's situation and conditions.

\section{RESULTS AND DISCUSSION}

Village development is an effort to improve the quality of life and life for the village community's maximum welfare (Indonesian Goverment, 2014). This law also stipulates that the empowerment of rural communities is an effort to develop community independence and welfare by increasing knowledge, attitudes, skills, behaviour, abilities, awareness, and utilizing resources through the establishment of policies, programs, activities and assistance following the essence of problems and priority needed by the community. The development of the Koto Sentajo tourism village still lacks attention from the Kuantan Singingi local government. Therefore, through community service programs carried out by their lecturers, universities try to make social innovation. Social innovation in tourism development is significant than what technology-based innovation offers (Lindberg et al., 2015).

\section{The Role of Higher Education in the development of the Tourism Village}

Universities, governments and other stakeholders have an essential role in formulating and implementing sustainable tourism development by utilizing existing tourism resources (Muzapu and Sibanda, 2016). Coordinated communication between stakeholders is critical in disseminating knowledge and public awareness regarding local community-based sustainable tourism development (Yasir et al., 2019). In this case, Riau University, through its academics as a stakeholder, has established communication with the community to develop Koto Sentajo Tourism Village. Assistance activities through the university's assisted village program have started since 2018. The support and mentoring of this university can even arouse other stakeholders' awareness of developing tourism villages.

Universities in Indonesia have an essential role in developing, assisting and empowering communities through community service programs. The development of a tourism village is the responsibility of villagers and any related stakeholders, including universities and the local government, through related agencies (Suyanto et al., 2019). The role of academics is vital as a catalyst for science, innovation, and bridging society's interests universally (Chamidah, et al., 2020; Chamidah, et al., 2020). In this case, the central government, through the Indonesia Ministry of Tourism and Creative Industries and the Indonesia Ministry of Villages and Development of Underdeveloped Regions, has created programs in collaboration with some universities to develop several new tourism village projects. Koto Sentajo Village has been choosen by Riau University as a tourism village project because it has various traditions, local wisdoms and community's ability to preserve custom-based environment. The development of community-based sustainable tourism by relying on the beauty of environment culture and nature can maximize tourist satisfaction. It can maintain ecological balance and lead to a restoration of peace among residents (Mohanty et al., 2019).

Developing Koto Sentajo Village as a tourism village based on preserving cultural heritage is very appropriate because a good tourism development must maintain tradition by involving the local community (Ali, 2018; Giampiccoli, 2020; Khamdevi and Bott, 2018). Community-based tourism assistance model delivers community assistances in developing tourism villages, preserve cultural traditions and maintain local wisdom of the community who cares deeply about environmental sustainability. On the other hand, market-oriented development policies are fundamental in the tourism sector because it can increase the existing tourism market's capacity. Due to the nature of intense global market competition, tourist destinations must be developed through communication and more innovative ways so that tourists tend to like them because tourist demand is even more varied when compared to previous years (Genç and Genç, 2017).

Koto Sentajo village is one of the villages that become the capital of Sentajo Sub-district. Previously, this area was known as Kenegerian Sentajo which was led by traditional leaders called as datuk. It was an indigenous territory that has been existed long ago before Indonesian's independence. Kenegerian Sentajo includes a communal area consisting of five villages, namely Pulau Komang, Muaro Sentajo, Koto Sentajo, Kampung Baru Sentajo, and Pulau Kopung. Koto Sentajo is become the center of Kenegerian Sentajo, place of rumah godang and an old mosque namely masjid usang raudhatul jannah. People of Sentajo are strongly tied to this village because it is the place where their ninik mamak (older leaders) gathers in rumah godang, and also the place in where Sentajo's customs are centered and enforced. The customs in Sentajo region were being preserved time to time. One part of the traditional heritage is the legacy of the rumah godang (godang house) and the traditions of the Sentajo's daily life. They have rituals, such as herding buffalo and calling them home by using salt liquid, menyintak as traditional fishing method using bamboo and nets and only doing by women, farming rice fields, gardening palm and rubber trees, and implementing traditional ceremonies, such as silek pandeka batuah (a kind of traditional bare hand martial art), maelo jalur (a ritual of cutting down a big tree as raw material for making a traditional boat namely jalur), pacu jalur (a tradition of boat racing during the commemoration of Indonesian independence day, and rayo kaduo (a tradition of gathering and discussing any topics among datuk-s, ninik mamak-s and villagers at rumah godang) .

Besides, there were also elements of ecology that support these cultural tourism potents, scuh as Kenegerian Sentajo protected forests, the Batang Kuantan (Kuantan river) banks, and the Kuantan Putuih lake. There were also traditional culinary delights, such as rondang paku, sambal karambial, puluik tungkuih, and agarwood leaf tea. All of those elements could be combined as natural tourist attraction packages to attract a lot of visitors. Riau University Assisted Village Program aims to help the community in managing the village based on existing tourism potentials. This community service 
activity helps indigenous villagers to create, develop and manage any tourism businesses based on their culture and natural environment. As a tourist destination, Koto Sentajo has to be supported by complementary facilities that need innovation, social capital, human capital and good leadership (Boes et al., 2016). The findings during this research showed that local government has lack of innovation to maintain these tourism resources. However, communication activities through mentoring by academics of Riau University helped them to learn how to explore and manage it well. In hence, the tourism strategy to increase the competitiveness of destinations must optimize economic performance by considering the lowest possible social and environmental impacts to create residents' welfare (Perles-Ribes et al., 2020).

This academic mentoring method was concerned to the activities of Tourism Awareness Groups (Pokdarwis), Village-Owned Enterprises (BUMDes), Farmer Groups, and other local stakeholders. It can accelerate the capability of villagers to be able to manage their own tourism resources independently. Village officials and these groups can be jointly responsible for designing and creating a tourist village based on the results and findings during the community service programs done by lecturer and students from Riau University. The orientation of CBT development and community culture is a new trend for tourists (Lundberg, 2017). It was belived to be able to preserve Koto Sentajo's culture, while it was being used as tourist attractions. Tradition and culture were proofing of the harmony and hospitality of the Sentajo villagers. Their local wisdom keeps the custom-forests in this village preserved. Datuk-s were the highest customary leaders as the persons to ask and discuss about any problems by nephews and grandchildrens regarding routine matters and essential daily activities in Kenegerian Sentajo. This tradition is firmly entwined and maintained by the godang house's existence as a place for Sentajo's people to gather, interact and communicate ech other. As the population increases, so does the number of houses. There were 27 godang houses and an old mosque as Islamic identity and heritage for Sentajo's peopla. Each unit godang house can accommodate around 125 - 150 people. These houses were accommodates four large ethnic groups members of Peliangs, Caniagos, Melayus and Patopangs, so as its tribal fractions such as Peliang Lowe, Peliang Soni and Patopang Tanjung. These tribal faction names did not mean that they had different datuk and ethnic customs. The existance of four datuks was for lead each ethnic group. And the fraction ethnic groups members have to follow their own datuk's regulation. Thus, the name of ethnic group fractions were only to show to where was rumah godang they should gather and sit during ethnic groups gathering on rayo kaduo.



Figure 1. Old Mosque Masjid Usang Raudatul Janah (Source: Primary Data, 2020)

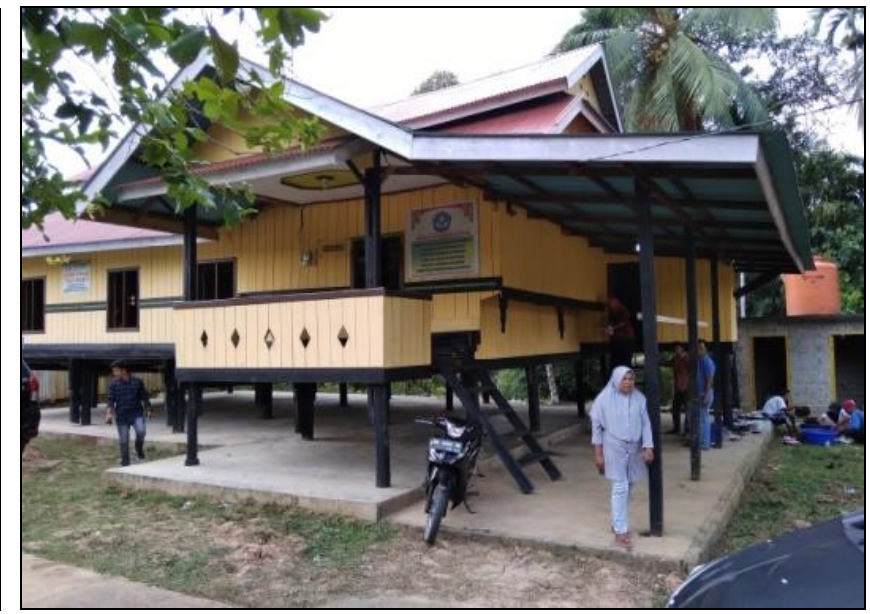

Figure 2. Patopang's Rumah Godang has been fuctioned as homestay (Source: Primary Data, 2020)

Koto Sentajo was legaized as a cultural heritage village according to the Decree of Kuantan Singingi Regent No 25 / Kpts / 11 / 2017. This decree stated the Koto Sentajo is registered as a tourist attraction. Even though the local gevernment had designated them as a tourist village, they cannot develop it without any further discussion to the datuks and ethnic group members. Therefore, this mentoring program provides several ongoing pieces of training conducted by universities and aims to build tourist villages. Understanding and knowledge of local community groups' attitudes are crucial in sustainable tourism development to help the success of the creation of tourist destinations (Lundberg, 2017).

Higher education has a vital role in opening the community's insights and expertise in managing tourist villages through intensive communication. Communication through open dialogue is essential because it helps understand community communication to build further bonds (Lafever, 2011). Coaching has carried out by forming and fostering Pokdarwis to manage Sentajo tourism resources. They were trained and assisted to prepare the tourist village's completeness to handle tourist arrivals. Some of Riau University lecturers trained people to maintain cleanliness and implement the so-called "Sapta Pesona" program, namely Cleanliness, Health, Safety and Environment Sustainability (CHSE). The community has driven to identify their potential tourist attraction and how to adjust to the targeted tourist segmentation. It is vital to continuously monitor changes in the tourist interest market to adapt to most tourists' needs (Santos et al., 2016).

The training and mentoring such as homestay management, tour guide, promoting tourism villages, and forming a Tourism Awareness Group (Pokdarwis) have carried out directly by providing examples for several village youths. The form of communication carried out by assistants, lecturers, and students by giving examples is the right step to take advantage of existing media. This communication activity has made the community aware of the importance of promoting 
the village through mass media and internet-based media. The information has developed professionally to attract tourists. Collaboration with a network of tourism activists makes Koto Sentajo Tourism Village news easy to spread via Instagram, Facebook, Twitter, and online news channels to be known to the broader community.

The tourism communication model must be carried out in an integrated manner to create an image of a tourist destination (Wang et al., 2009). Local communities, tourism village assistants and local governments become communicators in delivering messages related to the Koto Sentajo tourist village. Communication is vital to create tourist destinations, so activities must involve local communities by synergizing with other stakeholders (Yasir et al., 2019). In Koto Sentajo tourism village assistance, tourism communication channels have established using many communication channels, both interpersonal (person to person), groups, and organizations. Through assistance from the college, the communication activity then raises communication messages made in documentary films by conventional mass media such as television and feature news in printed media. This content is then uploaded to a private or institutional YouTube channel so that the image of Koto Sentajo Tourism Village spreads widely.

\section{Penta helix Communication Model in Tourism Village Development}

Communication plays an essential role in the development of a tourist village as a destination. Riau University has bridged communication with other stakeholders. Good collaboration between universities and stakeholders in this village based on an open attitude is essential for developing synergistic interactions between tourism stakeholders (Heslinga et al., 2017). Communication through partnerships is one of the most important things to establish a tourist village. Tourism communication does not merely inform tourism knowledge and messages on preserving culture and natural resources, but it becomes an integral part of developing sustainable communities, businesses and tourism products (Carr et al., 2016). Tourism and village development has many obstacles and limitations. Limited resources and networks in developing a tourism village have concerned in collaboration with various parties.

The tourism communication element by collaborating is the government, academics, private sector/business people, the community and the mass media to synergize or work together (Chamidah et al., 2020). This social innovation is known as the Penta helix model. Tourism communication elements must be able to play their respective roles. In this case, the government is the institution or communication actor most responsible for implementing the tourism village development policy. The government plays a vital role in policy planning, control, and evaluation and plays an essential role in promoting tourism villages (Putra, 2019). The local government bureaucracy of Kuantan Singingi Regency in developing the tourism village has not played a maximum role. The local government, from the bureaucratic side as the main actor in implementing public policies, has not yet fully developed Koto Sentajo Village's potential. The weak implementation of policies is also caused by the legislative function that is not maximal in carrying out legislation, budgeting and controlling related to regional tourism potential.

The local government plays an essential role in sustainably empowering communities. The principle of sustainability will influence rural tourism development's success, which can increase income for the village (Hairunisya et al., 2018). Community development, especially among young people, boosts the community's economic improvement and needs to be developed. Tourism village development must establish corporate CSR, mass media, and local communities for its sustainability. Sustainable government communication and coordination with other stakeholders can overcome the obstacles faced and even help accelerate the national tourism development program's success and improve rural communities' welfare. The next communication actor is higher education. The local community relies on higher education and academics to provide community service and expertise from conducting research and education activities. Higher education plays a role in generating innovation to form a science and knowledge-based society.

Related to this, five fundamental factors facilitate successful creation and its application to the university's social agenda, namely: institutional strategic policy commitment to social innovation; inclusive and institutionalized processes for advancing social innovation; community engagement approach; obligation to apply to license or use free of charge and open for research and innovation transfer processes; mobilization of internal and external resources to support social innovation (Halibas et al., 2017). Universities and academics with the knowledge, innovative skills, active and entrepreneurial innovation are the principal capital in creating smart tourist destinations (Boes et al., 2016). In disseminating information or applying technology, universities must collaborate and partner with other elements: government, community, business, and the mass media.

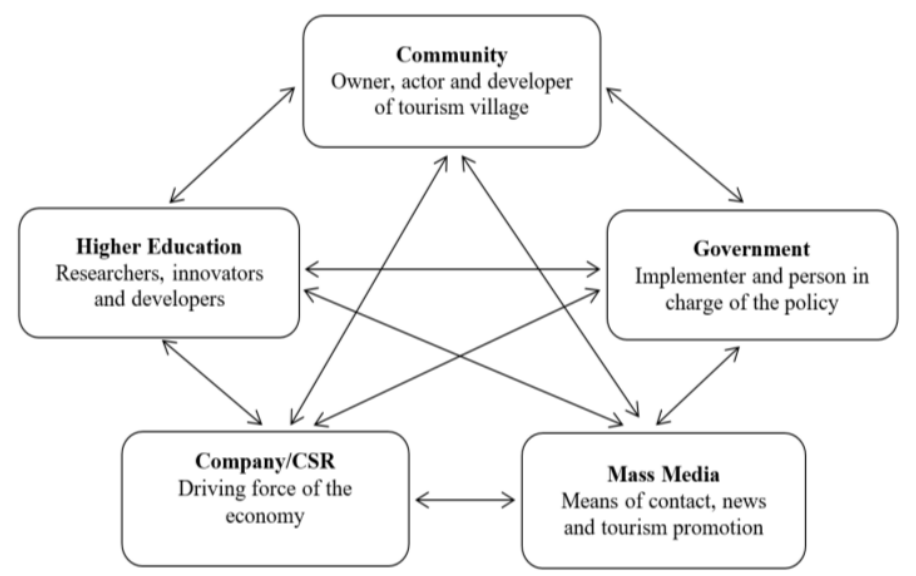

Figure 3. Penta helix Tourism Communication Model in the Development of Koto Sentajo Tourism Village (Source: Analysis of Research Data, 2020) The involvement of higher education is vital for the progress of the Koto Sentajo tourist village. Lecturers and students' ability to fuse and involve themselves in the community in developing a tourist village is crucial to stimulate young residents to be involved in village development (SinclairMaragh, 2017). Tourism development planning should focus on young groups because the internet and social media are 
mostly young people. Their creativity is essential in creating innovative tourism village products such as culinary delights, destination promotion, and the creation of other tourist attraction events. The segmentation of young millennial groups is targeted compared to older ones because they are more familiar with digital technologies looking for new and authentic experiences (Santos et al., 2016). As one of the penta helix elements, business institutions have played an essential role in driving the regional economy directly or indirectly. In Koto Sentajo Tourism Village, the role of companies such as through CSR is still lacking. Companies can use village tourism that already has the right image to enhance its appearance. The CSR program can be developed by establishing good cooperation with other stakeholders, such as creating cultural tourism objects as the main product. Koto Sentajo Village can also collaborate with travel companies, vehicle rentals, tourist business owners, hotels or inns, and other culinary businesses.

Companies, through CSR can get the right image with community empowerment activities because the village already has the right image in the minds of the community. Even CSR activities significantly affect companies' customer loyalty and reputation, such as hotels and travel agents (Hassan et al., 2021).The next actor is the local community. The village community plays a vital role in developing a tourist village because the community represents the products or characteristics of a tourist village (Chamidah, et al., 2020). As the owner of customary rights, the local community can be assisted by other communities such as the Generasi Pesona Indonesia (Genpi) Kuantan Singingi Regency, tourism activists, social media activists, and groups interests or hobbies related to tourism development. Community groups, such as Pokdarwis, are among the main stakeholders in developing and implementing tourism villages (Putra, 2019). The CBT concept explains the vital role of the community in tourism development. As the main development actor, the Koto Sentajo people have traditions and customs to become a means of preserving and maintaining cultural traditions and identity as spiritual aspects, sources of economic life and development of tourist villages. In other words, the development of community-based tourism villages can preserve the environment, social systems and community cultural values.

Mass media is the next important element or actor in tourism development. Mass media is not only a means of disseminating information, socializing and communicating policies, but mass media can be a significant player in the development of a tourist village. Conventional mass media, such as newspapers, radio or television, have been replaced by internet-based media. New media or social media such as Facebook, Instagram, Twitter, YouTube, and others can integrate the existing media's overall characteristics. Social interactions nowadays are straightforward and fast without being hindered by distance and time. Social media currently plays an essential role in marketing tourist destinations (Kakirala and Singh, 2020). Social media's ability to disseminate information on the Koto Sentajo tourist village without being limited by the dimensions of space and time has utilized the development of the Koto Sentajo tourist village, mostly through word of mouth. Information through word of mouth is essential because it can create an image and tourist destinations to increase competitiveness in a competitive market (Fan et al., 2018).

The government and village officials can directly promote the Koto Sentajo tourist attraction through social media. The emergence of accounts both officially managed by the government, community, and individuals has featured and recommended Koto Sentajo village as a tourist destination worth visiting. Social media has a significant influence in helping market products and developing small and medium business innovations (Basri and Siam, 2019).

Table 1. The Role of a Penta Helix Communication Actors (Source: Analysis of Research Data, 2020)

\begin{tabular}{|c|c|c|c|c|}
\hline University & Company/CSR & Government & Society & Media \\
\hline $\begin{array}{c}\text { Carrying out research, } \\
\text { creating innovations, } \\
\text { and developing tourist } \\
\text { villages. }\end{array}$ & $\begin{array}{c}\text { Synergize incorporate } \\
\text { and village promotion } \\
\text { programs }\end{array}$ & $\begin{array}{c}\text { Represented by the head of } \\
\text { the village and the } \\
\text { Department of Culture and } \\
\text { Tourism manages community } \\
\text { activities and bureaucratic }\end{array}$ & $\begin{array}{c}\text { Mapping and developing } \\
\text { the potential attractions or } \\
\text { products of cultural and } \\
\text { ecotourism tourism }\end{array}$ & $\begin{array}{c}\text { Inform the tourism } \\
\text { potential of the village } \\
\text { found and able to be } \\
\text { developed }\end{array}$ \\
\hline $\begin{array}{c}\text { To organizes a variety } \\
\text { of education and } \\
\text { training for human } \\
\text { resources as tourism } \\
\text { businesses. }\end{array}$ & $\begin{array}{c}\text { To provide funds or } \\
\text { needs in the } \\
\text { development of } \\
\text { tourism. }\end{array}$ & $\begin{array}{c}\text { Mapping tourism potential, } \\
\text { preparing regulations, and } \\
\text { allocating funds for tourist } \\
\text { villages }\end{array}$ & $\begin{array}{c}\text { As a service user and } \\
\text { business actor who } \\
\text { contributes to the } \\
\text { implementation and } \\
\text { development of tourism }\end{array}$ & $\begin{array}{c}\text { Introducing an } \\
\text { heritage to visit and } \\
\text { preserve }\end{array}$ \\
\hline $\begin{array}{c}\text { Collaborating with } \\
\text { central and local } \\
\text { governments to prepare } \\
\text { supporting facilities and } \\
\text { infrastructure }\end{array}$ & $\begin{array}{c}\text { Collaborating with } \\
\text { government, higher } \\
\text { education and society } \\
\text { to provide access and } \\
\text { amenities }\end{array}$ & $\begin{array}{c}\text { Fostering and training } \\
\text { communities, building } \\
\text { infrastructure for community } \\
\text { economic development and } \\
\text { tourism villages }\end{array}$ & $\begin{array}{c}\text { Strengthening Pokdarwis } \\
\text { and building relationships } \\
\text { with other communities } \\
\text { such as Genpi, } \\
\text { community activists, etc. }\end{array}$ & $\begin{array}{c}\text { Synergize with } \\
\text { stakeholders to promote } \\
\text { the development of } \\
\text { regional tourism } \\
\text { potential }\end{array}$ \\
\hline $\begin{array}{c}\text { Preparing graduates } \\
\text { who are ready to work }\end{array}$ & $\begin{array}{c}\text { Help set up community } \\
\text { access }\end{array}$ & $\begin{array}{c}\text { Developing, marketing } \\
\text { products and communicating } \\
\text { tourist destinations }\end{array}$ & $\begin{array}{c}\text { Develop and market the } \\
\text { products of village } \\
\text { tourism }\end{array}$ & $\begin{array}{c}\text { Developing a news } \\
\text { model that cares about } \\
\text { tourism }\end{array}$ \\
\hline
\end{tabular}

Through this Pantehelix model of tourism communication, all driving actors: universities, government, society, private companies, and mass media, must explore tourism potential, developing and maintaining cultural values. Communities such as the Genpi in Kuantan Singingi Regency and other tourism activists have a role in developing ideas and creativity, even promoting or providing input to the tourism village developer stakeholders. Each element of this Pantehelix model of tourism communication must carry out its role correctly to develop the tourist destination. Problems often faced in tourism development are weak coordination among stakeholders, low community participation, lack of funds, low awareness, and 
poor tourism marketing strategies (Eyassu et al., 2019). In this case, the local government is responsible for implementing tourism development policies in the regions as the leading agent. Therefore, regional governments must build exemplary communication and collaborate with other elements, namely: academics, companies, society and mass media as an inseparable unit because their existence is complementary to one another. In developing tourist villages, the central government, local governments, universities, tourism activists, the mass media, and the community have carried out tourism communication. The government, as the main element of penta helix is expected to be a pioneer capable of embracing all other penta helix aspects to work together collaboratively (Chamidah, et al., 2020). Various communication channels and media have utilized, but social media plays an essential role in spreading messages and shaping Koto Sentajo Village's image as a tourist village. Koto Sentajo, as a tourist village, is currently famous on social media as a cultural heritage tourism village in Riau Province and attaching an image as a traditional village that is still original and sustainable. Today, social media such as Facebook, Instagram and YouTube have established their essential role in promoting the destination's image in the text, audio and visual forms (Nghiêm-Phú and Bagul, 2020).

The communication process supporting the development of the Koto Sentajo tourist village still does not involve intensive cooperation between the five existing elements. The development of sustainable tourist destinations requires technological and institutional innovations (Van Wijk et al., 2015). The government and universities must be creative to involve their cooperation with corporate CSR to accelerate village tourism facilities or infrastructure. Also, the communication carried out by the local government is still limited to carrying out routine ceremonial tasks, even though the tertiary institution, through the mentoring program, has tried to foster the Koto Sentajo community in developing a tourist village. This activity is assisted in collaboration with the Ministry of Tourism and Creative Economy to nurture and train tourism village management, namely lecturers, students and tourism village managers. Concerning this tourism village development activity, the local government should have budgeted funds, added staff, proposed regular training and guidance programs for Pokdarwis, BUMDes, and farmer groups. This local government support is essential in accelerating tourist villages' development and controlling tourism village development sustainability.

Local governments are crucial stakeholders in tourism development (Heslinga et al., 2017). Through this local government activity, the village government of Koto Sentajo can manage well to make it a pilot tourism village, not only in Kuantan Singingi Regency but also in Riau Province.Higher education certainly does not always accompany the development of this tourism village. Local government policies must support the sustainability of implementing and evaluating tourism village development activities sustainably. This sustainable development is vital to achieving the desired goal: to become a developed and independent tourism village. This development activity requires creativity and innovation, not only for the local government but also for the community. In essence, the development of tourism in the development of community culture and infrastructure. Tourist destinations equipped with complete facilities can be a vital component in the management and marketing of tourist destinations (Boes et al., 2016). In developing on the heritage tourism village with the penta helix model, it needs to build stakeholder synergy with other supporting elements, such as substantial cooperation among academics, communities, government, business people and the media. There are five elements called penta helix (Lagarense et al., 2018). In the implementation, all parties work together and cannot walk alone and development based on digital innovation. Cooperation and collaboration are crucial in building a tourist village, especially in creating added value to the community's economy, strengthening social ties and increasing environmental awareness (Boes et al., 2016). Cooperation and collaboration are mandated by Law number 10 of 2009 concerning Tourism. Article 4 states that the goal of tourism is to increase economic growth; improve people's welfare; eradicating poverty; overcoming unemployment; conserving nature, environment and resources; promoting culture; lifting the image of the nation; cultivating a love of the country; strengthening national identity and unity, and strengthening friendship between nations. Therefore, it is imperative to develop a tourism village to support national tourism, which should be carried out with the principle of empowering local communities according to the mandate of the law.

\section{CONCLUSION}

Higher education has a significant role in empowering the community to develop a tourism village's potential. Academicians carrying out community service and innovation through research and education to grow an independent society. Lecturers and students involved themselves in indigenous people daily life and provoked other stakeholders to create Koto Sentajo Village Tourist hand in hand. Tourism communication for Koto Sentajo tourism village development involved many stakeholders known as the Pantehelix tourism communication model. This model involves five main actors driving tourism: universities, government, society, companies or CSR, and the mass media.

Each of these Pantehelix model tourism communication actors must carry out their roles properly to develop tourist destinations well. In this case, tourism development programs were still lack of coordination among stakeholders, low community participation, lack of funding allocation, low awareness, and inadequate tourism management and also marketing strategies. Communication activities carried out by local governments are still limited to carrying out routine ceremonial tasks. As a result, the communication process supporting the development of the Koto Sentajo tourism village in Kuantan Singingi Regency still does not involve intensive cooperation. Communication implementation was weak due to the low level of continuous coordination among penta helix stakeholders and digital innovation performance in all development programs. The local government was the main element who was responsible for this tourism programs. They were expected to be able to build exemplary communication and collaborate with other actors, including academics, companies, society, and the mass media as an inseparable units. Their existence was complementary to one another. Thus, the collaborations among them have to based on understanding, openness, 
common goals, and empathy that can build strong bonds among stakeholders. Besides, the development of sustainable tourist destinations requires social, technological and institutional innovation. The local government should have budgeted funds, added staff, and made routine training programs for Pokdarwis, BUMDes and farmer groups.

This official supports were significant in accelerating tourist villages' development and controlling its sustainability. Hereinafter, lecturers and university should continually synergize in doing village assistance program hand in hand to corporate CSR activities, the mass media, and local communities. It has been expected to carry out a fair problem solvings for both tourism development and conserve the community engagement in form of cultural-based tourism villages. In addition, this research should be developed using an ethnographic communication approach to gain understanding to support the right policies in the field of culture-based tourism. An impact study on the development of tourism village development also needs to be carried out for better management of development of cultural-based tourism village.

\section{Acknowledgement}

The authors would like to thank the Head of the Institute for Research and Community Service of Riau University for providing research and community service funding. Our thanks also go to the Ministry of Tourism and Creative Economy, which has provided training both to accompanying lecturers, students and the community of Koto Sentajo Village.

\section{REFERENCES}

Ali, A. (2018). Travel and tourism: Growth potentials and contribution to the GDP of Saudi Arabia. Problems and Perspectives in Management, 16(1), 417-427. https://doi.org/10.21511/ppm.16(1).2018.39

Bahri, B., \& Prasetyo, W. (2020). Pengentasan kemiskinan melalui pemberdayaan wirausaha dan program life skill untuk meningkatkan produktivitas kelompok UPPKS Kalipakem Baru (Poverty alleviation through entrepreneurial empowerment and life skill programs to increase the productivity of th. Riau Journal of Empowerment, 3(1), 27-37. https://doi.org/10.31258/raje.3.1.27-37

Basri, W.S.M., \& Siam, M.R.A. (2019). Social media and corporate communication antecedents of SME sustainability performance. Journal of Economic and Administrative Sciences. https://doi.org/10.1108/jeas-01-2018-0011

Boes, K., Buhalis, D., \& Inversini, A. (2016). Smart tourism destinations: ecosystems for tourism destination competitiveness. International Journal of Tourism Cities, 2(2), 108-124. https://doi.org/10.1108/IJTC-12-2015-0032

Carr, A., Ruhanen, L., \& Whitford, M. (2016). Indigenous peoples and tourism: the challenges and opportunities for sustainable tourism. Journal of Sustainable Tourism, 24(8-9), 1067-1079. https://doi.org/10.1080/09669582.2016.1206112

Chamidah, N., Guntoro, B., \& Sulastri, E. (2020). Marketing communication and synergy of pentahelix strategy on satisfaction and sustainable tourism. Journal of Asian Finance, Economics and Business, 7(3), 177-190. https://doi.org/10.13106/jafeb.2020.vol7.no3.177

Chamidah, N., Putra, A.H.P.K., Mansur, D.M., \& Guntoro, B. (2020). Penta helix Element Synergy as an Effort to Develop Tourism Villages in Indonesia. Jurnal Manajemen Bisnis, 8(1), 01-22. https://doi.org/10.33096/jmb.v8i1.625

Chiappa, G. Del, Atzeni, M., Pung, J.M., \& Risitano, M. (2019). Residents' views on cruise tourism in naples profiles and insights from a mediterranean home-port destination. European Journal of Tourism Research, 23, 71-85.

Do, Y., Kim, S.B., Kim, J.Y., \& Joo, G.J. (2015). Wetland-based tourism in South Korea: who, when, and why. Wetlands Ecology and Management, 23(4), 779-787. https://doi.org/10.1007/s11273-015-9418-2

Eyassu, A.W., Chekole, Y.A., \& Tadesse, G.T. (2019). Tourism development potentials and challenges in Shonke Village, Ethiopia. African Journal of Hospitality, Tourism and Leisure, 8(5), 1-16.

Fan, S., Chen, Y., Su, X., \& Cheng, Q. (2018). A study of effects of ecotourism environment image and word of mouth on tourism intention. Ekoloji, 27(106), 599-604.

Garcias, J.R. (2012). Community strategy for mangrove forest conservation: Conquista Campesina conservation easement. Field Actions Science Report, 7(SPL), 0-14.

Genç, R., \& Genç, E.A. (2017). Market-oriented innovations in tourism. Research in Hospitality Management, 7(1), 51-57. https://doi.org/10.1080/22243534.2017.1355606

Giampiccoli, A. (2020). A conceptual justification and a strategy to advance community-based tourism development. European Journal of Tourism Research, 25(2020), 1-19.

Gumede, T.K. (2019). Heritage tourism as a strategy for the local economic development in KwaZulu-Natal, South Africa. African Journal of Hospitality, Tourism and Leisure, 8(3), 1-15.

Hairunisya, N., Angraieini, D., \& Sri, M.A. (2018). Pemberdayaan di Sektor Pariwisata Sebagai Upaya Meningkatkan Perekonomian Masyarakat (Empowerment in the Tourism Sector as an Effort to Improve the Community's Economy). Jurnal Pengabdian Kepada Masyarakat, 1(2), 13-18.

Halibas, A.S., Ocier Sibayan, R., \& Lyn Maata, R. (2017). The Penta Helix Model of Innovation in Oman: An HEI Perspective. Interdisciplinary Journal of Information, Knowledge, and Management, 12 May, 159-174. https://doi.org/10.28945/3735

Hassan, T.H., Shehata, H.S., El-Dief, M., \& Salem, A.E. (2021). The social responsibility of tourism and hotel establishments and their role in sustainable tourism development in Al-Ahsa, Saudi Arabia. Geojournal of Tourism and Geosites, 33(4), 1564-1570. https://doi.org/10.30892/gtg.334spl18-609

Heslinga, J., Groote, P., \& Vanclay, F. (2017). Strengthening governance processes to improve benefit-sharing from tourism in protected areas by using stakeholder analysis. Journal of Sustainable Tourism, 9582(December), 1-15. https://doi.org/10.1080/09669582.2017.1408635

Hrycyk, H.C.P. de M., Gomes, B.M.A., \& Nitsche, L.B. (2020). Voluntary Tourism in Rural Space in Curtiba, Parana Brazil. Enlightening TOurism. A Pathmaking Journal, 10(1), 58-77.

Istiyanto, S.B. (2011). Komunikasi Pemerintah Daerah dalam Program Pembangunan Daerah Wisata Pantai Pascabencana (Regional Government Communication in Post-Disaster Coastal Tourism Area Development Program). Jurnal Ilmu Komunikasi, 9(1), 16-27.

Kakirala, A.K., \& Singh, D.P. (2020). The Mediating Role of Social Media in Tourism: An eWOM Approach. Journal of Asian Finance, Economics and Business, 7(11), 381-391. https://doi.org/10.13106/jafeb.2020.vol7.no11.381

Khamdevi, M., \& Bott, H. (2018). Rethinking tourism: Bali's failure. IOP Conference Series: Earth and Environmental Science, 126(1). https://doi.org/10.1088/1755-1315/126/1/012171 
Lafever, M. (2011). Empowering native Americans: Communication, planning, and dialogue for eco-tourism in Gallup, New Mexico. Journal of International and Intercultural Communication, 4(2), 127-145. https://doi.org/10.1080/17513057.2011.556829

Lagarense, B.E.S., Hidayah, T., \& Abdillah, F. (2018). Digital Technology and Pentahelix Role Model for Sport Tourism Event of IVCA 2018 in Bali. Proceedings - 2018 International Conference on Applied Science and Technology, ICAST $2018,263-270$. https://doi.org/10.1109/iCAST1.2018.8751618

Lindberg, M., Ericson, Å., Gelter, J., \& Karlberg, H. (2015). Social change through place innovation. Swedish Design Research Journal, 13 February 2017, 9-13. https://doi.org/10.3384/svid.2000-964x.1519

Lundberg, E. (2017). The importance of tourism impacts for different local resident groups: A case study of a Swedish seaside destination. Journal of Destination Marketing and Management, 6(1), 46-55. https://doi.org/10.1016/j.jdmm.2016.02.002

Martínez, R.M., Galván, M.O., \& Lafuente, A.M.G. (2014). Public Policies and Tourism Marketing. An Analysis of the Competitiveness on Tourism in Morelia, Mexico and Alcala de Henares, Spain. Procedia - Social and Behavioral Sciences, 148, $146-152$. https://doi.org/10.1016/j.sbspro.2014.07.028

Maxwell, J. (2014). Designing a Qualitative Study. In The SAGE Handbook of Applied Social Research Methods (Issue January 2008, 214-253. https://doi.org/10.4135/9781483348858.n7

Mohanty, P.P., Rout, H.B., \& Samal, A. (2019). Community based sustainable tourism development - A tool for fostering and promoting peace: A case study of Odisha, India. African Journal of Hospitality, Tourism and Leisure, 8(1), 1-15.

Moleong, L.J. (2010). Metode Penelitian Kulaitatif. Remaja Rosdakarya.

Mtapuri, O., \& Giampiccoli, A. (2020). Beyond rural contexts: Community-based tourism in urban areas. Advances in Hospitality and Tourism Research (AHTR), 9100, 419-439. https://doi.org/10.30519/ahtr.690184

Muzapu, R., \& Sibanda, M. (2016). Tourism Development Strategies in Zimbabwe. Management, 6(3), 55-63. https://doi.org/10.1109/CICN.2014.251

Nagarjuna. (2015). Local Community Involvement in Tourism: A Content Analysis of Websites of Wildlife Resorts. Atna - Journal of Tourism Studies, 10(1), 13-21. https://doi.org/10.12727/ajts.13.2

Nghiêm-Phú, B., \& Bagul, A.H.B.P. (2020). An extended model of destination image formation: The inclusion of sensory images. European Journal of Tourism Research, 24(2020), 1-10.

Noor, M.F., \& Nala, I.W.L. (2020). Pariwisata dan Pelestarian Ekosistem Sungai; Desa Pela dalam Upaya Konservasi dan Peningkatan Ekonomi Masyarakat (Tourism and River Ecosystem Conservation; Pela Village in Conservation Efforts and Community Economic Improvement). Literasi Nusantara.

Perles-Ribes, J.F., Ramón-Rodríguez, A.B., Moreno-Izquierdo, L., \& Such-Devesa, M.J. (2020). Tourism competitiveness and the well-being of residents: A debate on registered and non-registered accommodation establishments. European Journal of Tourism Research, 24, 1-16.

Pung, J.M., \& Chiappa, G.D. (2020). An exploratory and qualitative study on the meaning of transformative tourism and its facilitators and inhibitors. European Journal of Tourism Research, 24(2020), 1-21.

Putra, T. (2019). A Review on Penta Helix Actors in Village Tourism Development and Management. Journal of Business on Hospitality and Tourism, 5(1), 63. https://doi.org/10.22334/jbhost.v5i1.150

Ridlwan, M.A., Muchsin, S., \& Hayat, H. (2017). Model Pengembangan Ekowisata dalam Upaya Pemberdayaan Masyarakat Lokal. Politik Indonesia: Indonesian Political Science Review, 2(2), 141. https://doi.org/10.15294/jpi.v2i2.9933

Santos, M.C., Veiga, C., \& Águas, P. (2016). Tourism services: facing the challenge of new tourist profiles. Worldwide Hospitality and Tourism Themes, 8(6), 654-669. https://doi.org/10.1108/WHATT-09-2016-0048

Sinclair-Maragh, G. (2017). Demographic analysis of residents' support for tourism development in Jamaica. Journal of Destination Marketing and Management, 6(1), 5-12. https://doi.org/10.1016/j.jdmm.2016.03.005

Strydom, A.J., Mangope, D., \& Henama, U.S. (2019). Making community-based tourism sustainable: Evidence from the Free State province, South Africa. GeoJournal of Tourism and Geosites, 24(1), 7-18. https://doi.org/10.30892/gtg.24101-338

Sumarmi, Kurniwati, E., \& Aliman, M. (2020). Community based tourism (cbt) to establish blue economy and improve public welfare for fishing tourism development in klatak beach, tulungagung, indonesia. Geojournal of Tourism and Geosites, 31(3), 979-986. https://doi.org/10.30892/gtg.31307-530

Suyanto, E., Lestari, S., Wardiyono, F., Wuryaningsih, T., \& Widyastuti, T.R. (2019). Community Participation Model in Formulating Cross-Potential Mangrove Ecotourism Policies Supporting Kampung Laut Sustainable Tourism Village. 13(8), 1-9. https://doi.org/10.9790/2402-1308010109

Tripathi, G., \& Munjal, S. (2014). Heritage communication and sustainable tourism. Managing Sustainability in the Hospitality and Tourism Industry: Paradigms and Directions for the Future, 273-302. https://doi.org/10.1201/b16789

Van Wijk, J., Van der Duim, R., Lamers, M., \& Sumba, D. (2015). The emergence of institutional innovations in tourism: the evolution of the African Wildlife Foundation's tourism conservation enterprises. Journal of Sustainable Tourism, 23(1), 104-125. https://doi.org/10.1080/09669582.2014.927878

Wang, Y.J., Wu, C., \& Yuan, J. (2009). The role of integrated marketing communications (IMC) on heritage destination visitations. Journal of Quality Assurance in Hospitality and Tourism, 10(3), 218-231. https://doi.org/10.1080/15280080902988048

West, R., \& Turner, L.H. (2008). Pengantar Teori Komunikasi; Analisis dan Aplikasi. Salemba Humanika.

Yasir, Nurjanah, Salam, N.E., \& Yohana, N. (2019). Kebijakan komunikasi dalam membangun destinasi dan masyarakat sadar wisata di kabupaten bengkalis (Communication policies in building destinations and tourism-aware communities in Bengkalis district). Jurnal Studi Komunikasi (Indonesian Journal of Communications Studies), 3(November), 424-443. https://doi.org/10.25139/jsk.3i3.1548

*** Indonesian Goverment. (2014). Undang-Undang Nomor 6 Tahun 2014 Tentang Desa (Law Number 6 of 2014 concerning Villages). Jakarta, Indonesia.

*** Indonesian Government. (2009). Undang-Undang Nomor 10 Tahun 2009 Tentang Kepariwisataan (Law Number 10 of 2009 concerning Tourism).

Article history: Received: 28.02.2021 Revised: 15.06.2021 Accepted: 26.08.2021 Available online: 16.09.2021 